\title{
Pengaruh Pijat Oksitosin Terhadap Involusi Uteri Pada Ibu Postpartum di Rumah Bersalin Cuma Cuma Kota Bandung Tahun 2020
}

Fitriah Melinda Ainun, Retno Widowati*, Triana Indrayani

Fakultas Ilmu Kesehatan, Universitas Nasional, Indonesia

Corresponding author: Retno Widowati (retno.widowati@unas.ac.id)

Received: August, 2 2020; Accepted: August, 28 2020; Published: September, 12020

\begin{abstract}
ABSTRAK
Di Kota Bandung AKI mencapai 10/10.528 KH penyebab langsung kematian ibu diantaranya infeksi $10 \%$, atonia uteri $15 \%$, yang berdampak terjadinya perdarahan post partum Salah satu pencegahan penatalaksanaan dapat dilakukan dengan pemijatan oksitosin.

Penelitian ini bertujuan untuk mengetahui pengaruh pijat oksitosin terhadap involusi uteri pada ibu postpartum pada kelompok eksperimen dan kelompok kontrol.

Jenis penelitian ini adalah quasi experiment dengan rancangan pre-test dan posttestnonequivalent control group design. Populasi yang digunakan adalah seluruh ibu postpartum sebanyak 30 orang. Sampel terbagi menjadi kelompok eksperimen sebanyak 15 orang dan kelompok kontrol sebanyak 15 orang. Pengumpulan data dilakukan secara accidental sampling data dianalisis menggunakan Wilcoxon dan Mann-Whitney.

Ada perbedaan rata-rata terhadap involusi uteri pre-test dan post-test pijat oksitosin yaitu $\rho$ value 0,001. Dan ada perbedaan yang signifikan antara kelompok eksperimen dan kelompok kontrol setelah diberikan pijat oksitosin yaitu $\rho$ value $0,000<0,05$.

Pijat Oksitosin dapat mencegah perdarahan. Dan pijat oksitosin dapat diaplikasikan di Rumah Bersalin Cuma Cuma Kota Bandung.
\end{abstract}

Kata Kunci: Pijat Oksitosin, Involusi Uteri, Postpartum

This is an open-acces article distributed under the terms of the Creative Commons Attribution-ShareAlike 4.0 International License.

\section{PENDAHULUAN}

Menurut Word Health Organization (WHO) Angka kematian ibu (AKI) merupakan satu indikator yang dapat menggambarkan kesejahteraan masyarakat di suatu Negara. Di dunia pada tahun 2015 adalah 216 per 100.000 kelahiran hidup atau diperkirakan jumlah kematian ibu adalah 303.000 kematian. Kematian wanita usia subur diperkirakan sekitar 25-50\% penyebabnya adalah masalah kesehatan, persalinan, dan nifas (WHO, 2015). Kematian ibu dapat dipengaruhi oleh komplikasi kehamilan, persalinan, komplikasi nifas, riwayat penyakit ibu, riwayat KB, dan keterlambatan rujukan (Fitria,2012). Sedangkan penyebab kematian ibu nifas tertinggi adalahpendarahan $25 \%$, sedangkan komplikasi kedua tertinggi nifas sebanyak 20\%, riwayat penyakit ibu 20\%, infeksi 15\% mempengaruhi kematian ibu (Maritalia, 2014). 
Masa nifas dimulai setelah plasenta lahir dan berakhir ketika alat - alat reproduksi kembali seperti keadaan sebelum hamil (Lisnawati, 2013). Involusi uterus adalah proses perubahan organ reproduksi seperti sebelum hamil (lowdermik, 2012). Farrer (2011) menjelaskan bahwa Involusi uterus disebabkan oleh beberapa hal yaitu pertama akibat dari keluarnya hormon oksitosin yang menyebabkan terjadinya kontraksi dan retraksi otot miometrium uterus. Pijat oksitosin adalah suatu pemijatan tulang belakang mulai dari costa ke 5-6 sampai scapula akan mempercepat kerja saraf parasimpatis untuk menyampaikan perintah ke otak bagian tulang belakang sehingga oksitosin keluar (Sujiyatini, 2010). Pijat oksitosin dapat merangsang hipofisis anterior dan posterior untuk mengelurkan hormon oksitosin yang akan memicu kontraksi otot polos pada uterus sehingga akan terjadi involusi uterus (Pillitery, 2010).

Angka kematian ibu (AKI) akibat komplikasi nifas diAmerika Serikat sebesar 9 per 100.000 kelahiran hidup dengan penyebab tertinggi diakibatkan oleh perdarahan $25 \%$, di Inggris 11 per 100.000 kelahiran hidup dengan penyebab perdarahan 20\% dan infeksi 15\%. Di negara maju, akses layanan kesehatan lebih baik dibandingkan di negara-negara berkembang, sehingga tingkat kematian perempuan karena komplikasi kehamilan dan komplikasi nifas di negara maju lebih rendah dan penyebab tak langsung yang sebagian besar disebabkan interaksi antara kondisi medis sebelumnya dengan kehamilan (WHO, 2014). Hasil riset di London menyebutkan bahwa 20,4 \% pijat oksitosin berpengaruh untuk mencegah perdarahan postpartum (Hofmeyr, 2013). Di Negara berkembang kematian akibat komplikasi nifas adalah 28/100.000 kelahiran hidup penyebab tertinggi di akibatkan oleh pendarahan $25 \%$, Komplikasi nifas di Malaysia mencapai 29 per 100.000 kelahiran hidup dengan penyebab pendarahan 25\% dan infeksi 10\%. Di Vietnam komplikasi nifas 49 per 100.000 kelahiran hidup yang di sebabkan oleh pendarahan sebanyak 25\% (WHO, 2013). Berdasarkan hasil riset mengatakan bahwa $25 \%$ pijat oksitosin mencegah pendarahan postpartum dan mempercepat peroses involusi uterus (Sahal et al, 2015). Berdasarkan Data Survei Demografi dan Kesehatan Indonesia (SDKI) tahun 2015, AKI di indonesia sebesar 305 per 100.000 kelahiran hidup, kondisi ini disebabkan penyebab langsung AKI terutama oleh pendarahan 38,24\%, Infeksi dan eklamsia yang hanya diderita ibu hamil 5,88\%, penyebab lain persalinan lama,dan aborsi yang terkomplikasi, sedangkan peyebab tidak langsung seperti terlambatnya mengenali tanda bahaya, dan terlambat mencapai tempat persalinan. Adapun perdarahan yang terjadi adalah perdarahan post partum 15\% dari seluruh persalianan (BAPPENAS, 2017). Berdasarkan hasil tentang pengaruh pijat oksitosin terhadap Involusi uterus pada ibu postpartum sebagian besar respondennya 67\% mengalami penurunan TFU yang optimal (Hamranani, 2010).

Angka Kematian Ibu Berdasarkan laporan rutin Profil Kesehatan Provinsi tahun 2016 tercatat jumlah Kematian Ibu Bersalin 202 orang (21/100.000 KH), dan jika dilihat berdasarkan kelompok umur presentasi kematian pada kelompok umur $<20$ tahun sebanyak 71 orang (8,89\%), Cakupan Ibu Nifas yang mendapat pelayanan Kesehatan sesuai standar sebanyak 909.159 orang atau 97,61\% dari perkiraan jumlah Ibu Nifas di Jawa Barat, angka ini secara teknis program telah mencapai target yang besarannya ditetapkan 90\%, walaupun demikian Kota Cimahi 84,6\% masih belum mencapai target yaitu (Profil Kesehatan Jabar, 2016). Pada penelitian yang dilakukan di Indramayu, pemberian pijat oksitosin pada ibu postpartum normal dapat membantu proses involusi uterus terbukti dengan hasil penelitian sebanyak $70 \%$ responden terdapat pengaruh yang signifikan pijat oksitosin dengan involusi uterus (Aisyah, 2017).

Di Kabupaten Karanganyar pada tahun 2015 dari 16 kasus kematian ibu akibat komplikasi nifas sebesar 12 kasus meninggal dunia (75\%) dan pada tahun 2016 jumlah kematian ibu di Kabupaten Karanganyar sebesar 10 orang. Jumlah kematian ibu pada saat nifas pada tahun 2015 ditemukan terbanyak di puskesmas Karanganyar yaitu sebanyak 3 kasus (Dinkes Kab. Karanganyar, 2015). 
Berdasarkan data profil kesehatan kota Bandung Jumlah kasus kematian ibu di tahun 2017 kasus kematian ibu terjadi sekitar 10/10.528 KH. Penyebab langsung kematian ibu diantaranya infeksi $10 \%$, atonia uteri $15 \%$, yang berdampak terjadinya perdarahan post partum (Profil Kesehatan Kota Bandung, 2017). Berdasarkan hasil penelitian menunjukan, pijat oksitosin efektif untuk involusi uterus dan mepertahankan kontraksi uterus agar tidak terjadi perdarahan dan memperlancar produksi ASI (Khairani, 2012).

Menurut Sahal et al (2015) bahwa upaya untuk mencegah terjadinya perdarahan post partum adalah dengan memperbaiki kontraksi uterus yaitu melalui pemijatan oksitosin maupun dengan pemberian oksitosin. Pijatan yang dilakukan dimulai dengan ibu duduk rileks lalu dilakukan pemijatan dimulai dari leher hingga punggung dibatas bawah payudara, pemijatan menggunakan ibu jari dengan gerakan memutar. Pengeluaran oksitosin ini akan menyebabkan kontraksi dan retraksi uterus yang kuat, terus menerus sehingga dapat mencegah perdarahan post partum (Anggita, 2017). Menurut penelitian Susi (2020) menyebutkan bahwa ada pengaruh $(\mathrm{p}=0,03)$ pijat oksitosin yang dapat membantu melepaskan zat oksitosin terhadap proses involusi uteri. Hormon oksitosin akan menimbulkan kontraksi pada uterus dan dapat membantu proses involusi uterus yang lebih signifikan (Hidayati,2013).

\section{METODE}

Penelitian ini menggunakan metode quasi experiment dengan pendekatan nonequivalent control group design. nonequivalent control group design yaitu dalam rancangan pengelompokan anggota sampel pada kelompok eksperimen dan kelompok kontrol tidak dilakukan secara random atau acak. Populasi dalam penelitian ini adalah 30 orang ibu pasca salin 24 jam. Metode pengambilan sampel dalam penelitian ini menggunakan teknik nonprobability sampling dengan jenis accidentall sampling, dimana peneliti menentukan pengambilan sampel dengan cara mengambil kasus atau responden yang kebetulan ada atau tersedia di suatu tempat sesuai dengan konteks penelitian dengan kriteria inklusi yaitu pasca salin 24 jam yang mengalami persalinan normal, tidak menderita penyakit sistemik, sudah melakukan gerakan miring kanan miring kiri 2 jam pasca salin dan berdomisili di Bandung.

\section{HASIL}

Analisis Univariat

Tabel 1 Distribusi Frekuensi Involusi Uterus Sebelum dan Sesudah Diberikan Pijat Oksitosin pada Kelompok Eksperimen dan Kontrol di Rumah Bersalin Cuma Cuma Kota Bandung Tahun 2020

\begin{tabular}{lcccccccc}
\hline \multirow{2}{*}{ Involusi Uteri } & \multicolumn{3}{c}{ Eksperimen } & \multicolumn{3}{c}{ Kontrol } \\
\cline { 2 - 10 } & \multicolumn{2}{c}{ Pre-Test } & \multicolumn{2}{c}{ Post Test } & Pre-Test & \multicolumn{2}{c}{ Post Test } \\
\cline { 2 - 9 } & $\mathrm{f}$ & $\%$ & $\mathrm{f}$ & $\%$ & $\mathrm{f}$ & $\%$ & $\mathrm{f}$ & $\%$ \\
\hline Normal & 9 & 60 & 15 & 100 & 10 & 66,7 & 9 & 60 \\
\hline Tidak Normal & 6 & 40 & 0 & 0 & 5 & 33,3 & 6 & 40 \\
\hline Total & 15 & 100 & 15 & 100 & 15 & 100 & 15 & 100 \\
\hline
\end{tabular}

Berdasarkan tabel 1 dapat diketahui bahwa dari 30 responden pada kelompok eksperimen pada pre-test sebagian besar responden mengalami involusi uteri normal sebanyak 9 orang $(60 \%)$ dan yang mengalami involusi tidak normal sebanyak 6 orang $(40 \%)$ pada hasil post-test semua responden mengalami involusi uteri normal sebanyak 15 orang (100\%). Sedangkan kelompok kontrol pada pre-test sebagian besar responden mengalami involusi uteri normal sebanyak 10 orang $(66,7 \%)$ dan pada post-test tetap mengalami involusi uteri tidak normal sebanyak 6 orang $(40 \%)$. 
Analisis Bivariat

Tabel 2 Perbedaan involusi uteri sebelum dan sesudah dilakukan pijat oksitosin pada kelompok eksperimen dan kontrol Rumah Bersalin Cuma Cuma Kota Bandung Tahun 2020

\begin{tabular}{llccc}
\hline \multirow{2}{*}{ Pengukuran } & \multicolumn{4}{c}{ Involusi Uteri } \\
\cline { 2 - 5 } & $\begin{array}{c}\text { Eksperimen } \\
\text { Mean }\end{array}$ & $\begin{array}{c}\text { Kontrol } \\
\text { Mean }\end{array}$ & z & p-Value \\
\hline Pre-Test & 12,600 & 15,600 & $-3,433$ & 0,001 \\
\hline Post Test & 2,200 & 3,433 & $-3,437$ & 0,001 \\
\hline
\end{tabular}

Berdasarkan hasil analisis bivariat pada Tabel 2 di atas, menggunakan uji Wilcoxon pada kelompok eksperimen diperoleh hasil pre-test dengan mean sebesar 12,600 dan hasil post-test mengalami penurunan menjadi 2,200. Pada kelompok kontrol diperoleh nilai pre-test dengan mean 12,600 dan post-test 3,433. Didapatkan hasil analisis p-value sebesar 0,001<0,05 maka dapat disimpulkan bahwa ada perbedaan yang signifikan antara involusi uteri sebelum dan sesudah diberikan pijat oksitosin pada kelompok eksperimen dan kelompok control.

Tabel 3 Perbedaan involusi uteri sebelum dan sesudah dilakukan pijat oksitosin pada kelompok eksperimen dan kontrol di Rumah Bersalin Cuma Cuma Kota Bandung Tahun 2020

\begin{tabular}{lllc}
\hline Pengukuran & Mean & Median & p-Value \\
\hline Eksperimen & 10,466 & 10,500 & 0,000 \\
\hline Kontrol & 9,474 & 9,00 & \\
\hline
\end{tabular}

Berdasarkan hasil analisis bivariat pada Tabel 3 di atas menunjukan hasil uji perbedaan dua kelompok satu kali pengukuran (Mann-Whitney) yang menyatakan bahwa pada kelompok yang dilakukan Pijat Oksitosin dengan mean 10,466 dan pada kelompok yang tidak dilakukan pijat oksitosin dengan mean 9,474. Hasil analisa dengan menggunakan Mann-Whitney didapatkan hasil $\mathrm{P}$ value $=0,000<\alpha(0,05)$ yang menyatakan bahwa pada tingkat kepercayaan 95\% H0 ditolak yang berarti ada perbedaan rata-rata kelompok eksperimen dan kelompok control.

\section{PEMBAHASAN}

Distribusi Frekuensi Invousi Uterus Sebelum dan Sesudah Diberikan Pijat Oksitosin pada Kelompok Eksperimen dan Kontrol

Pijatan oksitosin dapat merangsang hipofisis anterior dan posterior untuk mengeluarkan hormon oksitosin, hormon oksitosin akan memicu kontraksi otot polos pada uterus sehingga akan terjadi involusi uterus (Sarwono, 2014). Sehingga dengan adanya penelitian ini dapat berpengaruh pada keluarnya hormon oksitosin dan membantu involusi uterus ibu.

Hal ini sejalan dengan riset yang dilakukan Sarli (2017) tentang pengaruh pijat oksitosin terhadap involusi uteri pada ibu postpartum di BPM Yetti Latief membuktikan bahwa terdapat pengaruh pemberian pijat oksitosin terhadap involusi uteri pada ibu postpartum. Didapatkan hasil dari penelitian $80 \%$ responden mempunyai TFU normal setelah diberikan perlakuan pijat oksitosin pada kelompok eksperimen dan pada kelompok kontrol $70 \%$ mempunyai TFU normal.

Hal ini sejalan dengan riset yang dilakukan Aisyah (2017) tentang pengaruh pijat oksitosin terhadap involusi uteri pada ibu postpartum bahwa Didapatkan hasil dari penelitian 14 responden (85\%) mempunyai TFU normal setelah diberikan perlakuan dan pada kelompok kontrol 70\% mempunyai TFU normal. Maka menurut meneliti adanya persamaan hasil involusi uetri antara kelompok eksperimen dan kontrol karena menggunakan responden yang sama yaitu pada ibu postpartum yang bersalin secara pervaginam. Observasi yang dilakukan peneliti menunjukan bahwa responden kelompok kontrol pun mengalami penurunan meski hanya sedikit kondisi ini terjadi karena faktor mobilisasi dan kondisi ibu menyusui dini pada saat 
habis melahirkan, faktor tersebut bisa menyebabkan terjadinya kontraksi uterus sehingga proses involusi uterus berlangsung normal.

Perbedaan Involusi Uteri Sebelum dan Sesudah Dilakukan Pijat Oksitosin Pada Kelompok Eksperimen dan Kontrol

Pijatan yang dilakukan kepada responen memang berpengaruh pada homron oksitosin sesuai dengan teori yang dijelaskann oleh Prawihardjo, 2014 bahwa Oksitosin merupakan suatu hormon yang diproduksi oleh hipofisis posterior yang akan dilepas kedalam pembuluh darah jika mendapatkan rangsangan yang tepat. Efek fisiologi dari oksitosin adalah merangsang kontraksi otot polos uterus baik pada proses saat persalinan maupun setelah persalinan sehingga akan mempercepat proses involusi uterus. Hal ini sesuai dengan penelitian yang dilakukan oleh (Khairani, 2012) bahwa pijat oksitosin berpengaruh terhadap involusi uteri pada ibu postpartum dengan $\mathrm{p}<0,05$, pijat oksitosin dapat membantu proses involusi uterus lebih maksimal pada ibu postpartum. Hal ini sejalan dengan penelitian yang dilakukan oleh Hamranani (2015) Teori diatas sejalan dengan penelitian ini dimana adanya kontraksi uterus yang kuat sebagai akibat dari intervensi peneliti berupa pijatan oksitosin yang menyebabkan penurunan tinggi fundus uterus pada responden bahwa rata-rata TFU pada ibu postpartum menurun setelah diberikan pijat oksitosin Didapatkan hasil dari penelitian menggunakanAnalisis serial Measurement dengan kemaknaan klinis digunakan mean dan confidence interval $95 \%$ dengan nilai $\mathrm{p}$ value $<\alpha(0,05)$ yang artinya ada pengaruh yang signifikan.

Maka menurut peneliti adanya persamaan hasil involusi uetri antara kelompok eksperimen dan kontrol karena menggunakan responden yang sama yaitu pada ibu postpartum yang bersalin secara pervaginam. Observasi yang dilakukan peneliti menunjukan bahwa responden kelompok kontrol pun mengalami penurunan meski hanya sedikit kondisi ini terjadi karena faktor mobilisasi dan kondisi ibu menyusui dini pada saat habis melahirkan, faktor tersebut bisa menyebabkan terjadinya kontraksi uterus sehingga proses involusi uterus berlangsung normal.

Penelitian ini dilaksanakan di Rumah Bersalin Cuma Cuma Kota Bandung terletak di JL. Holis No.448-A Caringin, Kec. Bandung Kulon, Kota Bandung, sendiri termasuk kedalam wilayah provinsi Jawa Barat dan meliputi 30 kecamatan yang terdiri dari 191 kelurahan. Secara geografis Kecamatan bandung kulon terletak disebebelah timur Kota Bandung dengan luas wilayah 647,3 Ha. Kecamatan Bandung Kulon ini terletak pada posisi lintang selatan dan antarabujur timur berada di 675 meter diatas permukaan laut. Kota Bandung memiliki 7 puskesmas PONED, 6 rumah sakit tipe A, 10 rumah sakit tipe B, 22 rumah sakit tipe $\mathrm{C}$ dimana masing-masing rumah sakit tersebut memiliki fasilitas dasar yang lengkap.

Metode pijat oksitosin dapat membantu mempercepat dan mencegah perdarahan, namun banyak yang belum mengetahui tentang metode dan manfaat pijat oksitosin. Sehingga disarankan ibu serta keluarga dapat menerapkan pijat oksitosin sebagai salah satu metode untuk mencegah perdarahan dan membantu mempercepat proses involusi uteri

\section{KESIMPULAN}

Berdasarkan hasil penelitian bahwa dari 30 responden ibu postpartum yang mengalamu involusi uteri pada kelompok eksperimen dan kelompok kontrol saat pre-test involusi uteri yang tidak normal pada kelompok eksperimen sebanyak 6 (40\%) responden dan $5(33,3 \%)$ responden untuk kelomok kontrol. Pada kelompok eksperimen terjadi penurunan angka involusi uteri menjadi tidak ada responden yang mengalami involusi uteri tidak normal. Peneliti membandingkan kelompok eksperimen dan kelompok kontrol dengan menggunakan uji Wilcoxon dan diperoleh hasil p-value $=0,001$ pada kelompok eksperimen dan kelompok 
kontrol karena nilai $\mathrm{p}<0,05$ maka dapat disimpulkan bahwa hasil hipotesis h0 ditolak artinya ada perbedaan bermakan pada pengaruh pemijatan oksitosin terhadap involusi uteri

\section{DAFTAR PUSTAKA}

Aisyah, Sastri, Nyimas., 2017, Pengaruh Pijat Oksitosin Terhadap Involusi Uterus Pada Ibu Pospartum, Vol XIII, at 2 http://ejurnal.poltekkes-tjk.ac.id, diakses 1 Mei 2020

Anggita, Intan., 2017, Pengaruh Pijat Oksitosin Terhadap Involusi Uterus Pada Ibu Masa Nifas Dengan Persalinan Normal Di Bidan Praktik Mandiri Wilayah Kerja Puskesmas Terisi Tahun 2016. www.ojs.stikesindramayu.ac.id

BAPPENAS. 2012. Laporan Pencapaian Tujuan Pembanguanan Millenium Di Indonesia. Jakarta.

Farrer, H., 2011, Perawatan Maternitas Edisi 2. Jakarta: Balai Pustaka.

Fitria, Maya H., 2012, Faktor - faktor yang Berhubungan dengan Pemakaian Kontrasepsi pada Wanita Pasangan Usia Subur di RSUD Pringadi Medan.

Hamranani., 2010, Pengaruh pijat oksitosin terhadap involusi uterus pada ibu post partum yang mengalami persalinan lama di rumah sakit wilayah Kabupaten Klaten. http://etd.repository.ugm.ac.id

Hofmeyr, Abdel-Aleem., 2013, Uterine Massage for Preventing Postpartum Haemorrhage

Khairani., 2012, Pengaruh Pijat Oksitosin Terhadap Involusi Uterus pada Ibu Post Partum di Ruang Post Partum Kelas III Rshs Bandung. http://jurnal.unpad.ac.id/ejournal/article 